\title{
Water Quantity and Quality Dimensions in Public and Environmental Health Among the Maasai of Amboseli Area, Kenya
}

\author{
M. M. Okello ${ }^{1}$, J. W. Kiringe ${ }^{1} \&$ Tome Salaton ${ }^{2}$ \\ ${ }^{1}$ The School for Field Studies, Center for Wildlife Management Studies, Kenya \\ ${ }^{2}$ Narok University College, Kenya \\ Correspondence: M. M. Okello, The School for Field Studies, Center for Wildlife Management Studies, P. O Box \\ 27743-00506, Nairobi, Kenya. Tel: 254-722-598-884. E-mail: mokello@fieldstudies.org
}

Received: April 16, 2014 Accepted: August 12, 2014 Online Published: August 19, 2014

doi:10.5539/enrr.v4n3p227

URL: http://dx.doi.org/10.5539/enrr.v4n3p227

\begin{abstract}
A comprehensive water situation analysis is critical in understanding linkages between environmental health, people and livelihoods. This study examined water and public health issues among the Maasai of Kimana near Amboseli National Park. Data was collected on the status, and trends in water quality and quantity, their causes and impacts to the local community using field assessment, interviews with local communities and laboratory analysis on water quality. Results indicated water quantity and quality were declining, and this was attributed to increase in human population, prevalence of irrigated agriculture, and recent climatic changes. The decline was thought to be contamination from human and livestock waste, proximity of homes to water sources, poor sanitation practices, agro - chemicals pollution, high levels of suspended solids and particulate matter. There was a general lack of enforcement by relevant agencies responsible for conservation and use of water resources. Due to communal ownership of resources and lack of resource stewardship, environmental degradation has become prevalent causing soil erosion which contributes to water contamination and sedimentation. A decline in water quantity and quality has led to increased prevalence of waterborne diseases such as dysentery, amoebiosis and typhoid. Therefore the water situation in the Kimana area is leading to negative consequences on the health of local communities. Appropriate intervention strategies are needed to promote sustainable water use and safeguard public health in the area.
\end{abstract}

Key words: Amboseli area, Maasai, public health, water quality, water quantity, waterborne diseases

\section{Introduction}

Water shortage and its sustainable use is a global concern. It is estimated that over $35 \%$ of the world has low levels of water supply (below $2000 \mathrm{~m}^{3}$ per year per capita, when $5000 \mathrm{~m}^{3}$ per capita per year is considered enough water) Wild Wildlife Fund for Nature (WWF) (www.wetland.azgro.nl \& www.panda.org/livingwaters). By the year 2025, most of countries in the world will be living under low (below $2000 \mathrm{~m}^{3}$ per capita per year) or catastrophically low (Figure 1) water supply levels (below $1000 \mathrm{~m}^{3}$ per capita per year). Kenya's water resources are increasingly threatened by pollution, degradation of water catchment areas and over - exploitation for economic development such as industries, domestic use and agricultural production through irrigation (GoK, 2005). Due to the impacts of water resources availability in economic development, health status and livelihoods of communities, Kenya's poverty reduction and economic recovery strategy for wealth and employment creation has strongly advocated for the implementation of structural reforms in water and sewerage services sectors (Mogaka, Gichere, Davis \& Hirji, 2006). The reforms are geared towards promoting integrated management of water resources and involvement of the local communities.

In 1995, Kenya was withdrawing less than $10 \%$ of available fresh water, but it is estimated that by 2025 , the country will be characterized by one of the world's highest withdrawal rates at over 40\% (Mogaka et al., 2006; www.wetland.azgro.nl \& www.panda.org/livingwaters). It's also postulated that by 2025 , it will be among 17 countries in Africa and the Middle East faced by an acute water shortage, leading to catastrophic declines in livelihoods, economic growth and health. This situation will also lead to local, regional and international conflicts in relation to water access and use rights. Of Kenya's total landmass of $582000 \mathrm{Km}^{2}$, only $16 \%$ is of medium to high rainfall potential (i.e. over $1000 \mathrm{~mm}$ per annum) and accounts for $20 \%$ of total agricultural land, and it's I in this area that $50 \%$ of the country's population is found (GoK, 2007). The medium potential areas which cover $35 \%$ 
of agricultural land receives $750 \mathrm{~mm}$ to $1000 \mathrm{~mm}$ of rainfall annually and supports 9 million people or $30 \%$ of total country's population. The rest of the country comprises $80 \%$ of the total landmass (classified as Arid and Semi Arid (ASAL), and is characterized by low rainfall averaging less than $750 \mathrm{~mm} / \mathrm{yr}$, and supports only $20 \%$ of total population (Pratt \& Gwynne, 1977; GoK, 2005; Mogaka et al., 2006). These statistics show that most of the country has scarce water resources.

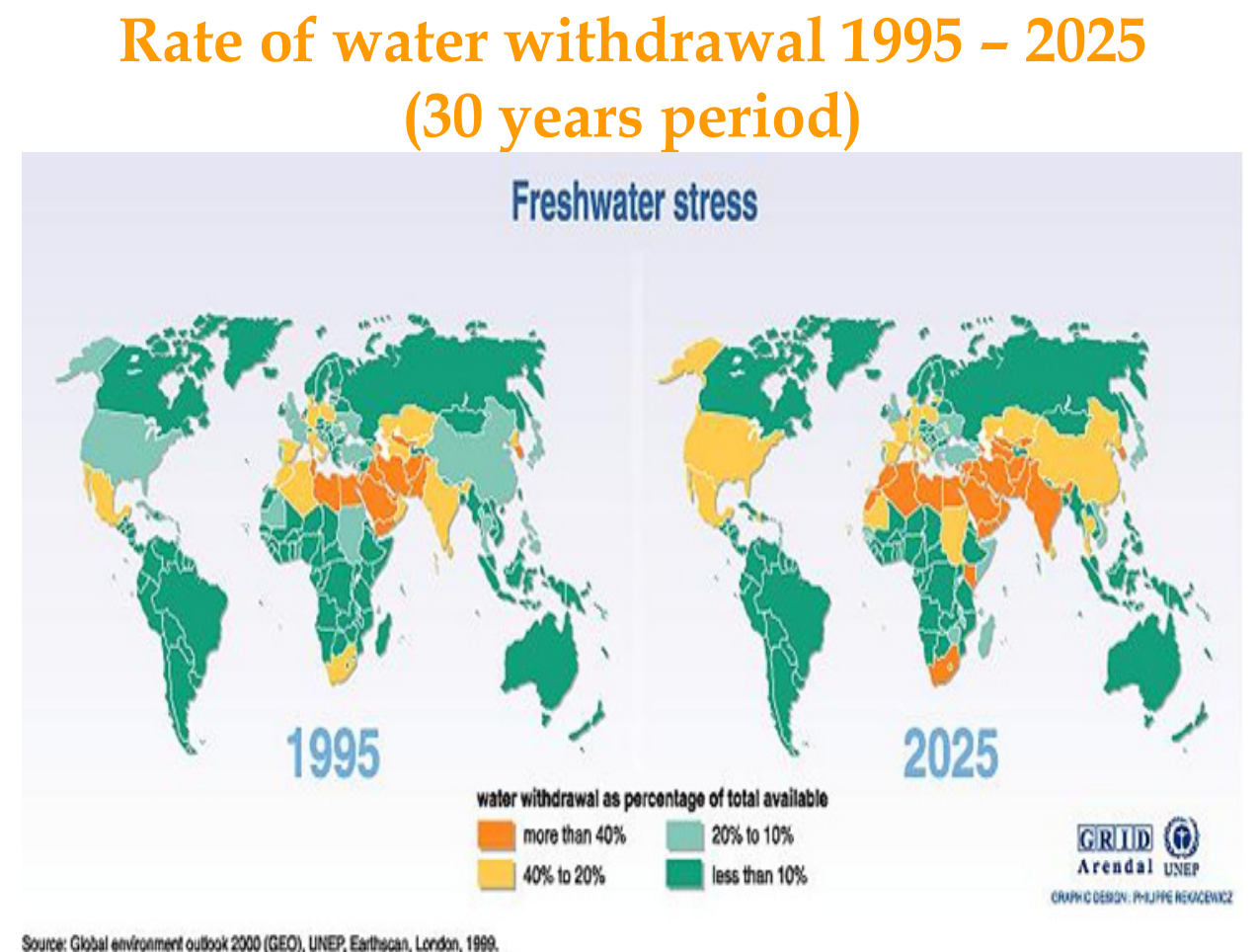

Figure 1. Global rate of water withdrawal between 1995 and 2025

Currently, the natural water endowment in Kenya is only 7.4 billion $\mathrm{m}^{3}$ of surface water, and 1 billion $\mathrm{m}^{3}$ of usable ground water (Gok, 2005; Mogaka et al., 2006). However, the annual per capita water endowment for the country is estimated at $650 \mathrm{~m}^{3}$ of fresh water annually (Mogaka et al., 2006). This per capita endowment is rapidly declining due to massive deforestation, frequent droughts, global warming and increased human population. Most of the water resources in the country are concentrated within the highland regions mainly Mt. Kenya, Aberdare, Elgon, Mau complex and the Cherengani Hills (GoK, 2007; Mogaka et al., 2006). However, these key catchment water areas have recently experienced extensive and severe environmental degradation which compromises their water resource potential and production (GoK, 2007). Among other impacts, this scenario is adversely affecting the agricultural sector by hindering expansion of rain fed agriculture, necessitating crop production through irrigation to enhance productivity (Gok, 2005; Mogaka et al., 2006).

Kenya has a potential land of about 539000 ha for irrigation and 600000 ha for irrigation potential (Gok, 2007). However, only 20\% (110 $000 \mathrm{ha}$ ) has been developed for irrigation, while only 5\% (30 000 ha) has been developed for drainage purposes. Constraints to sustainable development of irrigation and drainage have been lack of policy, inadequate irrigation and drainage infrastructure, lack of adequate funding, lack of research and support services, weak farmer associations and participation, and inadequate marketing strategies of farm produce (GoK, 2007). Future growth and development of agriculture will therefore rely on efficient use of land in medium and high potential areas, as well as use innovative use of ASAL's water resources through efficient irrigation techniques, provision of support services, and a national policy on irrigation and drainage, with associated legal and institutional framework.

The Economic Recovery Strategy for Wealth and Employment creation (ERS) in Kenya considers installation of irrigation facilities in ASAL's as a critical strategy to enhance food production and security (Gok, 2005, 2007; Mogaka et al., 2006) Vision 2030 has therefore prioritized agriculture as a major driver of economic development in the country by the year 2030. To achieve this, the policy on irrigation and drainage development has been 
proposed to stimulate irrigation and drainage through technical support, investment in the sector, improved research and extension services, and capacity building in farmer organizations. The policy also emphasizes on proper co-ordination of sector institutions, reform of existing institutions, and development of institutional and legal frameworks for irrigation and drainage development (GoK, 2007).

This study was done in the Kimana area of the Amboseli region near the Kenya-Tanzania border. The region is primarily an arid and semi-arid land, with a bimodal rainfall varying between 350 and $500 \mathrm{~mm}$ annually (Western \& Lindsay, 1984; Campbell, Lusch, Smucker \& Wangui, 2003; Okello, 2005). The main source of water for humans, Maasai livestock and wildlife comes from Mt. Kilimanjaro in Tanzania where rainfall is over $800 \mathrm{~mm}$ annually (Campbell et al., 2003). From this mountain, a number of surface and underground perennial streams flow down to the plains, feeding both the Amboseli swamp system and critical rivers like the Rombo, Noolturesh and Kimana-Kikarangot (Githaiga, Robin, Muchiru, \& Sandra., 2003). Historically, nomadic pastoralism by the Maasai people was the primary land use in the Kimana area and the entire Amboseli region (Kimani \& Pichard, 1998; Campbell et al., 2000; Ntiati, 2002), and did not create any serious competition between humans and wildlife over water resources (Okello \& D'Amour, 2008). However, in the early 1970s, non-Maasai ethnic groups like the Kamba and Kikuyu migrated to the region to capitalize on the rain-fed agricultural potential in the fertile land along the slopes of Mt. Kilimanjaro (Ntiati, 2002). Soon the slopes could not supply enough land for all of the immigrants, so land adjacent to permanent water sources in the dry rangelands like those of Kimana area have been turned into farms with furrow irrigated agriculture (Campbell et al., 2003; Okello \& D'Amour, 2008).

The expansion of irrigated agriculture in the Kimana area coupled with increasing human population (estimated at $3.7 \%$ per year) has caused uncertainty in availability, quality, access and sustainable use of water resources (Okello \& D'Amour, 2008). Most springs and water catchments are getting degraded by overgrazing and inappropriate human activities like farming causing massive soil erosion especially during the rainy season which compromises the water quality due to siltation. Agriculture has been found to consume $400 \%$ more water than humans and animals consume combined, placing tremendous pressure on the limited water resources (Okello \& D'Amour, 2008). With degradation of spring's vegetation cover important ecosystem services are minimized, including filtration of water and control of sedimentation (Reid et al., 2004). Loss of these ecological services coupled by increased pollution through extensive use of agro-chemicals, poor environmental protection ethics among locals, and inappropriate handling of human waste are key threats to water quality, and ultimately public health. Water use efficiency is also not enforced by the government in spite of existing policies, and there is rampant loss of large quantities of water through poor irrigation methods, and collectively this creates a shortage for users along many springs. Overall, the unsustainable use of water resources leads to frequent shortages and forces the community to use unclean water making them prone to water-borne diseases.

Recent evaluations on the status of Millennium Development Goals (MDGs) implementation and progress, for the Sub-Saharan countries has indicated the need to spur economic growth to double its current rate (4.7 to 9\%) in order to meet their targets (Mogaka et al., 2006). Additionally, the need to localize the goals has also been emphasized. Addressing sustainable water resources management in this initiative will foster the attainment of these goals (locally) as well as other national priorities such as achieving the goals set out by the Poverty Reduction Strategy (PRS), National Poverty Eradication Plan (NPEP), and the recently launched economic blue print Vision 2030 among numerous other local and regional initiatives. Considering that water is the bedrock of local livelihoods in the Kimana area, and its quality is a threat to public health, there is a need to understand its status, trends in quality and quantity, and casual factors. The findings will enable the government, local communities and other stakeholders in the water sector to craft interventions that will promote sustainable water use and its contamination. In this regard, the overall aim $\mathrm{f}$ this this study was to undertake a holistic water situation analysis, factors affecting water quality and quantity and effects on local communities' health.

The specific objectives of this study were to:

i. Assess water quality and quantity in the local community in Kimana area

ii. Establish local opinions in the trends and causal factors in water quality and quantity in the Kimana area

iii. Make inferences and recommendations on the effects of the water situation on public health of local community

\section{Area Description}

The Kimana area is one of the localities within Kimana Group Ranch (KGR) endowed with water resources. KGR is covers an area of about $251.2 \mathrm{Km}^{2}$, and is one of the six communally owned ranches by the Maasai community, 
and is located in Loitokitok District of the Amboseli region (Figure 2). Most of the Ambosel region including KGR comprises of arid and semi-arid lands (ASALs), are characterized by low rainfall which is bimodal varying between 400 and $500 \mathrm{~mm}$ annually, and is greatly influenced by Mt. Kilimanjaro. Most of the Kenyan side of Mt. Kilimanjaro is on the rain shadow, rainfall is therefore often patchy and unpredictable.

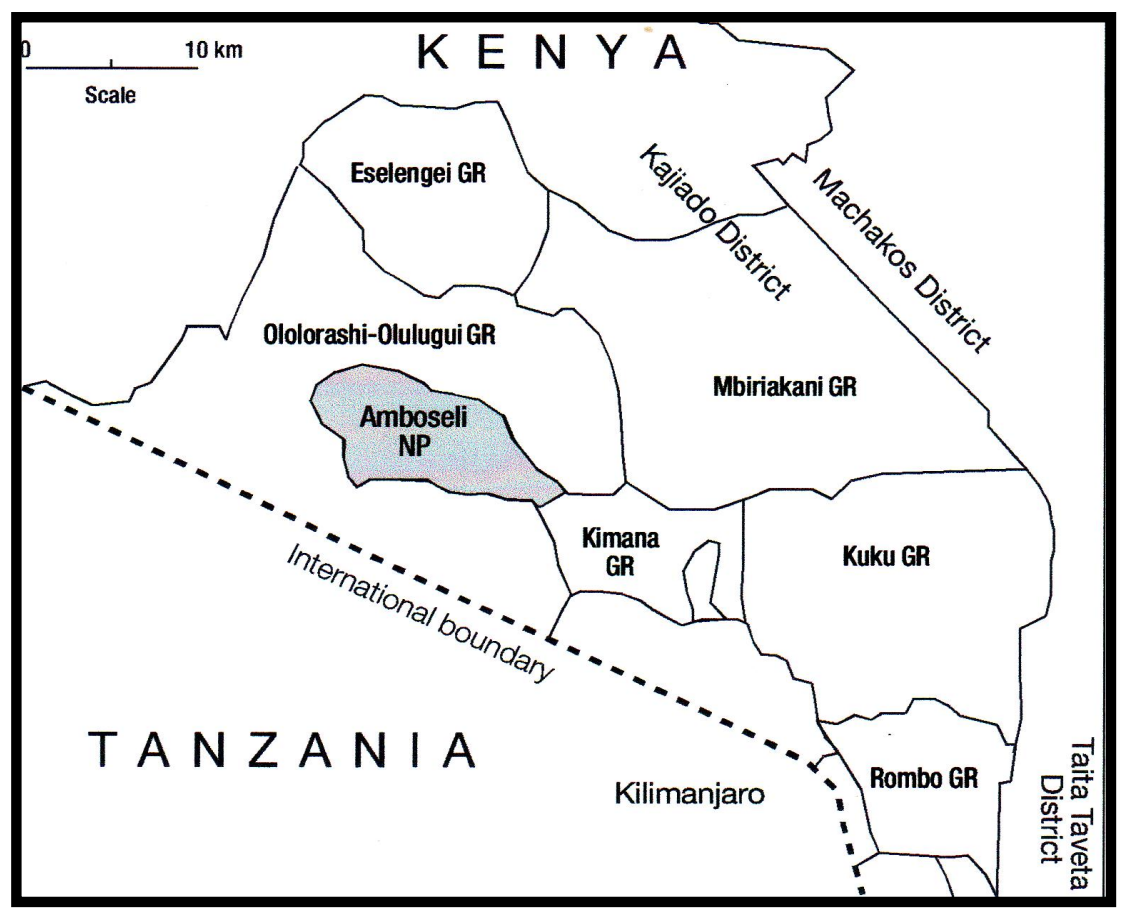

Figure 2. Group Ranches of the Loitokitok District, within the greater Tsavo - Amboseli ecosystem. Source: Kenya Wildlife Service (1996)

Rainfall regime in the Amboseli region is bimodal (Katampoi et al., 2005) and is influenced by Kenya's location in the Inter-Tropical Convergence Zone. The short rainy season occurs between end of October and mid-December, while the long rains occur between March and May (Kiringe \& Okello, 2005). Specifically, KGR receives an average of $210 \mathrm{~mm}$ of rain per annum with the short and long rains accounting for $30 \%$ and $45 \%$ respectively (Katampoi et al., 1990). Due to poor rangeland soils, low and unreliable rains, most of KGR is unsuitable for rain-fed agriculture, but recently irrigated agriculture had become very popular making it a leading economic activity after pastoralism (Ntiati, 2002; Campbell et al., 2003; Okello \& D'Amour, 2008). Overall, rainfall in the entire Amboseli region shows a high degree of spatio-temporal inconsistency with drought conditions being a common and frequent phenomenon. Since 2000, the rainfall pattern appears to have changed Thus, drought conditions are now a usual occurrence in the region and these have been recorded in the past for example in 1933-35, 1943-46, 1948-49, 1952-53, 1960-61, 1972-76, 1983-84 and the early 1990s. This puts a lot of pressure and demand on water resources and precipitates serious conflict and competition between local communities, livestock and wildlife.

Traditional livestock production has been the main economic activity of the Maasai people in KGR and most of the Amboseli region (Ntiati, 2002; Okello 2002; Kioko, Kiringe \& Seno, 2012) but in the last few decades, the Loitokitok District (which Kimana Group Ranch is part of) has experienced tremendous land use changes especially introduction of irrigated and rain-fed agriculture in the early 1970 s due to diverse cultural, political and economic forces(Ntiati, 2002; Campbell et al., 2003) KGR has therefore become an important horticultural production zone within the region. Irrigated agriculture is largely concentrated around important wetlands such those of Isinet, Namelok and Kimana swamps and also key riverine systems particularly within the Kimana fence where a high population of the Maasai people and non-Maasai migrants resides (Figure 3). With the erection of the European Union funded electric fences at Namelok and Kimana in 1999 at a total cost of about Ksh 42 Million, agricultural expansion has significantly increased. Today, most of the original landscapes including wetland areas have been cleared to give way to horticultural crop production. The significant aspects have been rampant 
diversion of water, loss of water through inefficient furrow systems, drying of rivers downstream and heavy fertilizer and pesticide use. Conflicts over water have arisen when insufficient clean water is not available downstream for both people and livestock. Wildlife use of habitats downstream is also being disrupted through lack of adequate water outside the Kimana fence where most of agriculture takes place.

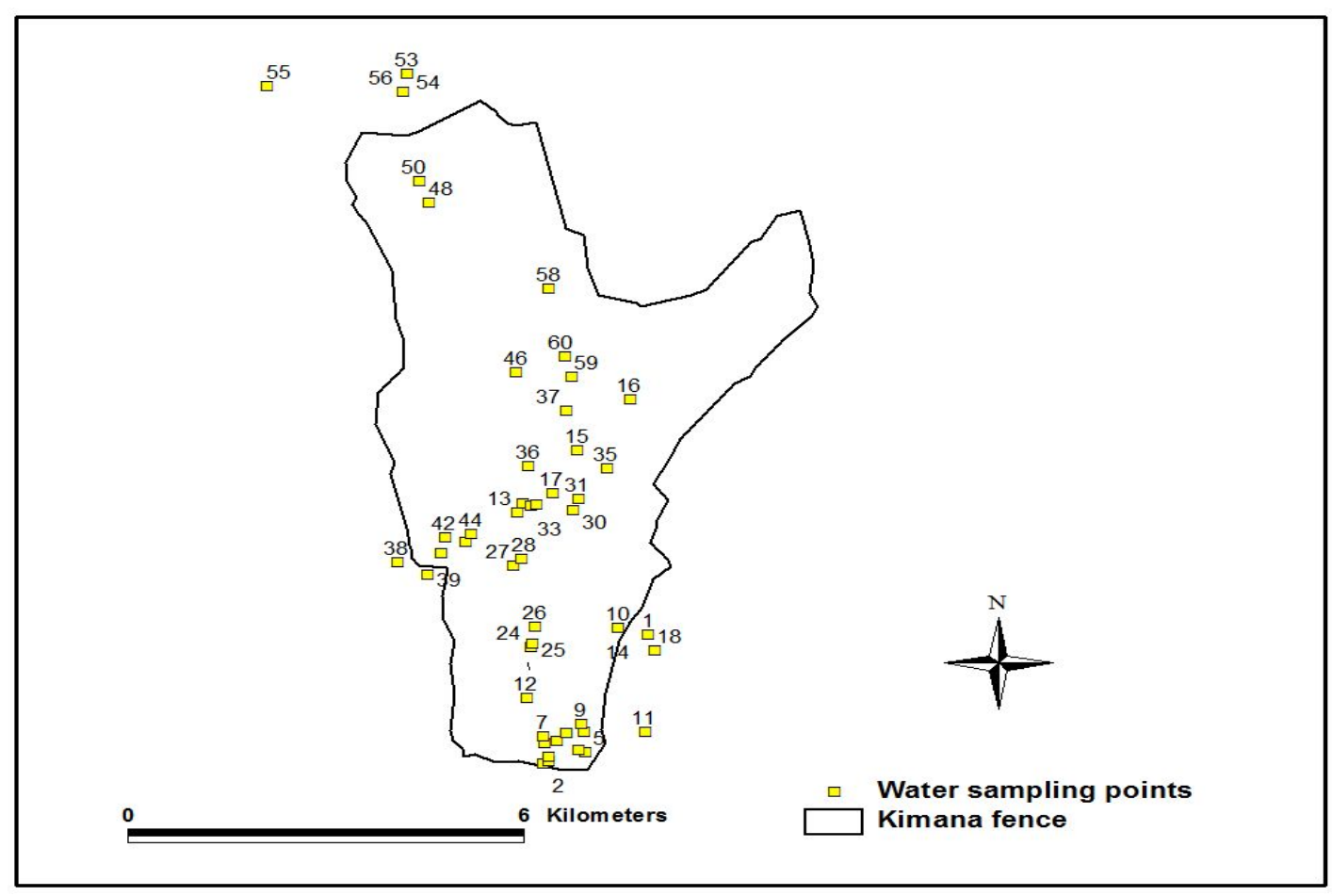

Figure 3. Water sampling sites for quality analyses

\section{Methods}

\subsection{Local Opinions on Status and Trend in Water Quantity and Quality}

A single round household survey (SRHS) was conducted between February and March 2009. Information was collected on 326 individuals at three sites (Imiron, Tikondo and Elerai) using a standardized questionnaire administered at the household level by locally trained Maasai enumerators. The number of households on each furrow at each site was obtained from the furrow management committee from which random samples were taken. The number was predetermined on the basis of the size of each agricultural cluster. The questions assessed the views of the respondents on; the main source of household water, status of water resources, trends in water quantity and quality and factors responsible of any notable changes. Other aspects which were also examined included prevalence and trends of water conflicts and waterborne diseases. Further, discussions were held with key informant local community members (leaders and health practitioners) to get more insights on the opinions emerging from the respondents. Household responses were keyed and entered in a statistical package (Statistical Package for Social Scientists-SPSS version 18) from which the frequency of various responses were calculated and where appropriate, these were statistically compared using Chi-square goodness of fit test and Chi-square contingency test. The responses from the key informants were collated and summarized in form of tables.

\subsection{Assessment of Water Discharge and Quality}

Stream discharge rates were taken at various river sources in the sites (Figure 3) using standard water volume discharge equipment. In order to establish whether water resources were fit for human consumption, sixty (60) water samples were collected at different points along streams, rivers and irrigation furrows (Figure 3) for chemical and bacteriological analyses and compared to recommended standards by the World Health Organization (WHO), Kenya Bureau of Standards (KEBs) and National Environment Authority (NEMA).

Samples were collected at the discharge point, middle and the lower sections of rivers and streams while along the irrigation furrows, samples were collected at the starting point of such furrows, middle and lower sections. All the 
sampling was undertaken in a manner that ensured representative variety of water sources and systems that are found in the three study sites. The rationale used to collect water samples at the beginning, middle and lower sections of the water systems was based on the assumption that water quality is expected to decline as water flows along these systems. All samples were preserved in cold storage before delivery to Nairobi (Kenya) with the analysis of most samples being undertaken 24 hours after sample collection.

The testing was undertaken in the Public Health Laboratory in the School of Engineering at University of Nairobi which is one of the NEMA accredited water quality testing laboratories in Kenya. Correlation tests were done to establish the relationship between non-compliant water parameters (i.e. turbidity, total hardness, total solids and total coli form count) with explanatory variables. Simple linear regression analysis was done between water quality parameters (turbidity and river/furrow channel) and environmental characteristics where the water samples were collected. Data analysis was conducted using SPSS statistical package. The chemical and biological indicator parameters used in the water quality situational analysis were based on Mackereth et al. (1989), and twenty four (24) parameters were analyzed for each water sample. The parameters were; $\mathrm{pH}$, apparent and true water colour, conductivity, turbidity, calcium and total hardness, alkalinity, iron, fluoride, sulphates, silica, dissolved oxygen, nitrates manganese, phosphates, chlorides, copper, chromium, dissolved and suspended solids, total coli forms and faecal coli form (Escherichia. coli).

\subsection{Assessment on the Environmental Status Around Water Sampling Points}

At all points where water samples were taken for analysis, the status of the environmental was assessed in terms of the extent of soil erosion, vegetation cover and land uses. Specifically, there was scoring for vegetation cover, types of crops grown, degree of soil erosion, visible water usage and proximity to human dwellings. At each sampling point, the four compass directions were noted, and scoring for the dominant vegetation cover was done by visually estimating the percent cover of the vegetation (such as woodlands, grassland, shrubland) (Mueller-Dombois \& Ellenberg, 1974). Scoring for vegetation cover was scored as follows: 1 for $71 \%$ to $100 \%$ cover; 2 for plant cover between $30 \%-71 \%$, and 3 for less than $35 \%$. The site was further characterized by the vegetation cover type present (such as trees and under story grass, trees with bare ground, grass cover only, bare ground, and cultivated banks).

Scoring for soil erosion at sampling points was also done in the four compass directions within a radius of 50 meters from the sampling point. Erosion status was scored based on whether there was no visible and type of erosion. Specifically, scoring was classified as 'no erosion', 'minimal rills', 'moderate erosion' and 'severe gully erosion. Scoring for land uses close to the water sampling points was done as well, and if there were any crops closer to the point, these were noted, including their proximity to the water sampling point. Further scoring was also done on the type of water uses around the sampling points such as irrigation for agriculture, livestock watering troughs, chemical spraying areas for livestock to control ticks and other ecto- parasites, and other uses.

The distance of human dwellings close to the water sampling point was measured. Such dwellings were in the form of Maasai homesteads (bomas) and for other ethnic groups, and all the housing units within it were counted. Presence or absence of a toilet facility was noted and their distance from the watering point measured. Site characteristics were summarized by tallying frequencies of different vegetation cover classes and dominant vegetation types along rivers / springs and furrow water courses where water sampling was done. The frequencies of crop types as well degree of erosion along these water courses were also determined. The number of homesteads (and associated house units), number of toilets in each homestead, and the distance of the homestead and toilet facilities to the watercourse was also established. The environmental characteristics along course ways of the three study sites (dominant woody vegetation cover, vegetation cover classes, degree of soil erosion, and type crops grown) were compared using Chi - square cross - tabulations. Analysis of variance (ANOVA) with a Tukey HSD Multiple Comparison Test (as appropriate) (Zar, 1999) among sites on the number of homesteads, housing units per homestead, number of toilets in each homestead, and the distance to water sources of each homestead was also done.

\subsection{Types of Waterborne Diseases and Their Prevalence in the Study Site}

The types and prevalence of waterborne diseases in the Kimana area was surveyed by examining the disease diagnosis and treatment records for 2008 in various government and private medical facilities found in the area. Data on disease diagnosis was categorized into the specific disease types and patient numbers tallied. Summaries of waterborne disease types for each season (wet: November - December; March - May) and dry: Jan - February; June - October) were summarized for each study site (i.e. Impironi, Tikondo and Elerai). Similarly, summaries of the number of patients suffering from various waterborne diseases for each site were obtained for each season, the type of health facility (whether private or private) where they sort treatment, and overall prevalence for each type 
of waterborne disease in each study site were also done. Chi - square cross - tabulations were used to establish whether season, type of health facility used by locals, types of waterborne diseases and the season when they were prevalent were dependent on the study sites.

\section{Results}

\subsection{Local Opinions on Status and Trend in Water Quantity and Quality}

A total of 322 respondents were interviewed, with males comprising about $53 \%(\mathrm{n}=52.8 \%, \mathrm{n}=170)$ of the sample and women constituting approximately $47 \%(47.2 \%, \mathrm{n}=152)$ of the sample. According to the respondents the main sources of water for the locals in the three sites came from streams and springs (Table 1), and more than $80 \%$ of community members got their water from these sources (Table 2). Other sources of water were shallow wells and piped water, and use of the water sources was dependent on location of the respondents $\left(\chi^{2}=199.025, \mathrm{df}=8\right.$, $\mathrm{p}<0.01$ ), with some sites overwhelmingly being dependent on one particular source (Table 2 ). A majority of locals in Impiron (72\%) sourced their water from springs, while $47 \%$ and $54 \%$ got their water from streams respectively. Another important water source for $33 \%$ of members in Tikodo was irrigation furrows.

Table 1. Local opinions on water use and quantity issues in Kimana Area

\begin{tabular}{|c|c|c|c|c|}
\hline Information sought & Responses & Frequencies & $\begin{array}{l}\text { Chi-square } \\
\text { goodness of fit }\end{array}$ & $\begin{array}{l}\text { Sample } \\
\text { size }\end{array}$ \\
\hline \multirow[t]{2}{*}{ Gender distribution } & Male & $170(52.8)$ & \multirow{2}{*}{$\begin{array}{l}\chi^{2}=1.006 ; \mathrm{df}=1 ; \mathrm{p} \\
=0.316\end{array}$} & \multirow[t]{2}{*}{322} \\
\hline & Female & $152(47.2)$ & & \\
\hline \multirow{5}{*}{$\begin{array}{l}\text { Sources of water used by the community } \\
\text { members }\end{array}$} & Spring water & $194(60.2)$ & \multirow{5}{*}{$\begin{array}{l}\chi^{2}=375.18 ; \text { df }=1 \\
p<0.001\end{array}$} & \multirow{5}{*}{322} \\
\hline & River / stream water & $75(23.3)$ & & \\
\hline & Piped water & $10(3.1)$ & & \\
\hline & Borehole / well water & $4(1.2)$ & & \\
\hline & Running furrow water & $39(12.0)$ & & \\
\hline \multirow{2}{*}{$\begin{array}{l}\text { Whether the amount of water (quantity) } \\
\text { was sufficient }\end{array}$} & Yes, its sufficient & $265(82.8)$ & \multirow{2}{*}{$\begin{array}{l}\chi^{2}=137.81 ; \text { df }=1 \\
p<0.001\end{array}$} & \multirow{2}{*}{320} \\
\hline & No, not sufficient & $55(17.2)$ & & \\
\hline \multirow[t]{6}{*}{ Reason for insufficient water quantity } & Human and animal interference & $2(5.4)$ & \multirow{6}{*}{$\begin{array}{l}\chi^{2}=20.24 ; \mathrm{df}=5 ; \mathrm{p} \\
=0.001\end{array}$} & \multirow[t]{6}{*}{37} \\
\hline & $\begin{array}{l}\text { Drought / dry season / climate } \\
\text { change }\end{array}$ & $12(32.4)$ & & \\
\hline & Many domestic water needs & $4(10.8)$ & & \\
\hline & $\begin{array}{l}\text { Inefficient water distribution } \\
\text { time table }\end{array}$ & $13(35.2)$ & & \\
\hline & Longer distance to water & $4(10.8)$ & & \\
\hline & Increase in human population & $2(5.4)$ & & \\
\hline \multirow[t]{3}{*}{$\begin{array}{l}\text { How individuals can help in resolving } \\
\text { water quantity shortage }\end{array}$} & $\begin{array}{l}\text { Securing the source (cementing } \\
\text { and fencing) }\end{array}$ & $7(29.1)$ & \multirow[t]{3}{*}{$\begin{array}{l}\chi^{2}=13.29 ; \mathrm{df}=2 ; \mathrm{p} \\
=0.001\end{array}$} & \multirow[t]{3}{*}{42} \\
\hline & Provide water by pipeline & $10(23.8)$ & & \\
\hline & Dig boreholes / wells & $25(59.5)$ & & \\
\hline \multirow{3}{*}{$\begin{array}{l}\text { How entire community can help in } \\
\text { resolving water quantity shortage }\end{array}$} & Help with water treatment & $1(2.1)$ & \multirow{3}{*}{$\begin{array}{l}\chi^{2}=27.44 ; \mathrm{df}=2 ; \mathrm{p} \\
<0.001\end{array}$} & \multirow{3}{*}{46} \\
\hline & Providing water by pipeline & $30(65.2)$ & & \\
\hline & $\begin{array}{l}\text { Cement irrigation canals and } \\
\text { furrows }\end{array}$ & $15(32.6)$ & & \\
\hline \multirow{2}{*}{$\begin{array}{l}\text { Whether water quantity from primary } \\
\text { source has changed with time }\end{array}$} & Yes, it has & $137(47.4)$ & \multirow{2}{*}{$\begin{array}{l}\chi^{2}=0.78 ; \mathrm{df}=1 ; \mathrm{p} \\
=0.38\end{array}$} & \multirow{2}{*}{299} \\
\hline & No, it has not & $152(52.6)$ & & \\
\hline \multirow{3}{*}{$\begin{array}{l}\text { The trend in water quantity changes over } \\
\text { recent times }\end{array}$} & Same & $73(36.3)$ & \multirow{3}{*}{$\begin{array}{l}\chi^{2}=50.99 ; \mathrm{df}=2 ; \mathrm{p} \\
<0.001\end{array}$} & \multirow{3}{*}{201} \\
\hline & Declined & $105(52.2)$ & & \\
\hline & Increased & $23(11.4)$ & & \\
\hline \multirow{4}{*}{$\begin{array}{l}\text { Reasons for the decline of water quantity } \\
\text { over time in recent past }\end{array}$} & Human population increase & $5(10.9)$ & \multirow{4}{*}{$\begin{array}{l}\chi^{2}=16.96 ; \mathrm{df}=3 ; \mathrm{p} \\
=0.001\end{array}$} & \multirow{4}{*}{46} \\
\hline & Climate change / drought/ & $23(50.0)$ & & \\
\hline & Water furrows cementing & $11(23.9)$ & & \\
\hline & Furrow mismanagements & $7(15.2)$ & & \\
\hline
\end{tabular}


A significant $\left(\chi^{2}=137.81 ; \mathrm{df}=1 ; \mathrm{p}<0.001\right)$ majority of those interviewed $(82.8 \%)$ noted that water quantity was sufficient compared to $17.2 \%$ who were of the view that it was insufficient (Table 1). Those who indicated that the water available was inadequate attributed this to drought and climatic change, inefficient water distribution and equitability, increase in human population, wastage due to un-cemented irrigation furrows (Table 1). Relatively fewer number of respondents $(47.4 \%)$ mentioned the quantity of water from their primary their sources had changed with time, even though this was not significantly $\left(\chi^{2}=0.78 ; \mathrm{df}=1 ; \mathrm{p}=0.38\right)$ greater than those who indicated $(52.6 \%)$ it had not. To resolve the problem of insufficient water for community use, the respondents suggested various solutions such as; provision of piped water from government owned Noolturesh pipeline, securing/protecting water sources, sink boreholes, and cement irrigation furrows (Table 1). When asked about the trend in water quantity, a significant majority of the interviewees (52.2\%), indicated there was a decline $\left(\chi^{2}=50.99\right.$; $\mathrm{df}=2 ; \mathrm{p}<0.001$ ), compared to $36.3 \%$ and $11.4 \%$ who indicated it had not changed, and had increased respectively (Table 1).

Key informants were of the view that water quantity and availability had declined over time (Table 3). They attributed this to the increase in human population and hence increased water demand, lack of community awareness on water changes, and water wastage by various users, and increased demand for irrigated agriculture. Some of the notable consequences of poor water use were increased sedimentation and siltation of rivers, with some rivers permanently drying out, decline in water quantity and increased prevalence of waterborne diseases (Table 2).

Table 2. Primary sources of water in the Kimana water project sites

\begin{tabular}{lcccccc}
\hline \multirow{2}{*}{$\begin{array}{l}\text { Water project } \\
\text { site }\end{array}$} & \multicolumn{5}{c}{ What is the primary source of the water you use } & $\begin{array}{c}\text { Sample size } \\
\text { (n) }\end{array}$ \\
\cline { 2 - 6 } & Spring & $\begin{array}{c}\text { River } / \\
\text { Stream }\end{array}$ & $\begin{array}{c}\text { Piped } \\
\text { water }\end{array}$ & $\begin{array}{c}\text { Borehole / } \\
\text { well }\end{array}$ & $\begin{array}{c}\text { Furrow irrigation } \\
\text { water }\end{array}$ & 146 \\
Impironi & $72 \%$ & $18 \%$ & $5 \%$ & $3 \%$ & $3 \%$ & $98 \%$ \\
Tikondo & $14 \%$ & $47 \%$ & $6 \%$ & $1 \%$ & $6 \%$ & 78 \\
Elerai & $5 \%$ & $54 \%$ & $27 \%$ & $8 \%$ & & $32 \%$ \\
\hline
\end{tabular}

\subsection{Assessment of Water Discharge and Quality}

The water discharge or flow rate from springs and streams at the source were constant and it is after 'production' that there was a reduction due increased abstraction at the middle and downstream sections (Table 4). Consequently, almost or nearly all water resources of the Kimana sub-catchment were $n$ over abstracted except the Kimana River which had a balance flow of $0.225 \mathrm{~m}^{3}$ per second. However, despite this volume, the out flow from Kimana wetland measured at Esambu- Kikarankot River showed a reduction in the flow rate $\left(0.132 \mathrm{~m}^{3}\right.$ per second $)$. Further, in the case of the Kikarankot River, most of its water was fully utilised for irrigation down stream leaving no environmental flow. This over - abstraction was not confined to this river but was also was observed for many springs and steams leading to a situation where there was almost no flow into the swamps and wetlands as it used to happen in the past. These swamps and wetlands were also not able to recharge ground water due to over exposure at catchment level and in the farms. 
Table 3. Opinions of key government officials on water quantity and quality related issues

\begin{tabular}{|c|c|c|}
\hline Information sought & Ministry of Agriculture & Provincial administration (Chief) \\
\hline $\begin{array}{l}\text { Water quantity } \\
\text { issues: status, trends } \\
\text { and causes of water } \\
\text { quality dynamics in } \\
\text { the Kimana area }\end{array}$ & $\begin{array}{l}\text { - Water availability has been declining } \\
\text { since the 1980's because of increase in } \\
\text { water users over the years, increase in } \\
\text { human population in Kimana Area in the } \\
\text { recent past, increase in irrigated } \\
\text { agriculture, use of wasteful voluminous } \\
\text { extraction of water that also cause heavy } \\
\text { pollution, such as water pumps, } \\
\text { - Need to diversify income have increased } \\
\text { irrigated cultivation hence demand for } \\
\text { water sharing, } \\
\text { There is increased crop som are } \\
\text { meaning that some farms ation and } \\
\text { continuously under cultivation } \\
\text { hence continuous water demand and use } \\
\text { - Sedimentation seals off spring } \\
\text { underground channels, hence reducing } \\
\text { the water discharge on the surface }\end{array}$ & $\begin{array}{l}\text { - There is acute water scarcity and } \\
\text { limited distribution throughout the } \\
\text { area } \\
\text { - } \quad \text { Corruption, inefficient and lack of } \\
\text { transparency in water furrow } \\
\text { management leads to serious } \\
\text { disparities in water quantity } \\
\text { distribution } \\
\text { - Water vendors' activities are not } \\
\text { controlled. Their presence has } \\
\text { exacerbated water shortage. } \\
\text { - Unfortunately, WRMA has not } \\
\text { done enough to raise awareness on } \\
\text { the roles and responsibilities of the } \\
\text { different stakeholders. } \\
\text { Additionally, WARMA should } \\
\text { collaborate with the furrow } \\
\text { management with a view to } \\
\text { imparting new skills especially } \\
\text { There are two rivers (Noolmatisia } \\
\text { and Impiron) flow has been greatly } \\
\text { altered and they don't run the full } \\
\text { course }\end{array}$ \\
\hline
\end{tabular}

Information from medical practitioners from both public and private practices in Kimana Area

\section{Information sought}

Water quantity issues: status, trends and causes of water quality dynamics in the Kimana area

Consequences of water dynamics in quality and quantity

$$
\text { Private clinics }
$$

Public clinic officers

Declining water quantity due to increase in irrigated agriculture, increase in human population and associated water demand, expanding Kimana town and water demand, and water vendor activities in the area

Amoebiasis; Diarrhea associated with vomiting (more prevalent in children); Typhoid (prevalent)

- Lublia cysts, Giardia worms, liver flukes, cholera (1997 - 1998), schistosomiasis.

- Waterborne diseases expected to continue to due faith and over dependence on unproven herbal medical care
- Declining due over -utilization as well as destruction of water catchment areas.

- High demand from expanding population and water selling as a business

- Diseases such as dysentery; amoebiasis; typhoid prevalence

- Market day eating cause transfer and contamination from the food from markets especially if consumed without washing

- When hands are not washed well before eating, the diseases spread and are difficulty to control 
Table 4. Rate of flow in cubic metres per second $\left(\mathrm{m}^{3} / \mathrm{s}\right)$ of the different water sources

\begin{tabular}{|c|c|c|}
\hline Name of the river & Canal or furrow & Water discharge volume $\left(\mathrm{m}^{3} / \mathrm{sec}\right)$ \\
\hline Tributary of Kimana & & 0.035 \\
\hline Isinet river & Kalesirua & 0.090 \\
\hline Isinet river & & 0.074 \\
\hline Loltulelei & & 0.013 \\
\hline Kikarankot river & & 0.132 \\
\hline Kimana river at RGS & & 0.133 \\
\hline \multirow[t]{2}{*}{ Kimana at zebra camp } & & 0.225 \\
\hline & Tikodo A & 0.006 \\
\hline \multirow[t]{2}{*}{ Kimana middle spring } & & 0.041 \\
\hline & Isinet spring- kimana canal & 0.052 \\
\hline Impiron (left side spring) & & 0.022 \\
\hline Impiron middle spring & & 0.034 \\
\hline \multirow[t]{3}{*}{ Impiron springs } & & 0.009 \\
\hline & Impiron middle and right side springs combined- A & 0.009 \\
\hline & Impiron End of canal & 0.014 \\
\hline Impiron springs (middle of river) & & 0.017 \\
\hline \multirow[t]{2}{*}{ Enkapune spring at source } & & 0.027 \\
\hline & Start of Enkapune furrow $\mathrm{C}$ & 0.018 \\
\hline \multirow[t]{5}{*}{ Kimana 2 springs combined } & & 0.129 \\
\hline & Kisioke & 0.024 \\
\hline & Enkapune middle of furrow $\mathrm{C}$ & 0.014 \\
\hline & Enkapune end of furrow $\mathrm{c}$ & 0.012 \\
\hline & Tikodo furrow A middle & 0.009 \\
\hline \multirow[t]{2}{*}{ Lotulelei spring } & & 0.075 \\
\hline & Loltulelei furrow A (middle of canal) & 0.014 \\
\hline Kimana & & 0.132 \\
\hline \multirow[t]{7}{*}{ Loltulelei spring } & Loltulelei river balance after furrow A & 0.044 \\
\hline & Loltulelei and ma salamwana & 0.052 \\
\hline & Loctulelei singh canal & 0.016 \\
\hline & New tikodo furrow B middle & 0.013 \\
\hline & New Tikodo furrow B end & 0.005 \\
\hline & Impiron fullow A & 0.018 \\
\hline & Impiron fullow A & 0.010 \\
\hline Impiron fullow A End & & 0.013 \\
\hline Enkeeni & & 0.002 \\
\hline Enkeeni & & 0.002 \\
\hline Enkeeni \& Impiron & & 0.002 \\
\hline Masala Mwana & & 0.011 \\
\hline Impiron & & 0.01 \\
\hline Tikodo river (end of right side spring -impironi) & & 0.009 \\
\hline \multirow[t]{2}{*}{ Kimana Right spring } & & 0.061 \\
\hline & Loctulelei furrow D & 0.014 \\
\hline \multirow[t]{8}{*}{ Loltulelei river after furrow $\mathrm{D}$ balance } & & 0.030 \\
\hline & Loctulelei furrow $\mathrm{C}$ & 0.009 \\
\hline & New tikodo furrow A starting & 0.013 \\
\hline & New tikodo furrow $\mathrm{C}$ end & 0.009 \\
\hline & New Tikodo furrow $\mathrm{C}$ start & 0.010 \\
\hline & New Tikodo furrow B middle & 0.014 \\
\hline & Impiron left side & 0.020 \\
\hline & Impiron & 0.011 \\
\hline \multirow[t]{2}{*}{ New Tikodo spring at source } & & 0.043 \\
\hline & New Tikido furrow $\mathrm{C}$ & 0.010 \\
\hline Lolmatasia & & 0.001 \\
\hline
\end{tabular}


Thirteen parameters were found to be within WHO, KEBs and NEMA standards for drinking water and irrigation in Kenya (Table 5). These included; electrical conductivity $(284 \mu \mathrm{S} / \mathrm{cm})$, Calcium hardness $(31 \mathrm{mg} / \mathrm{l})$, total hardness $(83 \mathrm{mg} / \mathrm{l})$, Sulphates $(66 \mathrm{mg} / \mathrm{l})$, Phosphates $(0.02 \mathrm{mg} / \mathrm{l})$, Silica $(65 \mathrm{mg} / \mathrm{l})$, Nitrates $(1.7 \mathrm{mg} / \mathrm{l})$, Manganese $(0 \mathrm{mg} / \mathrm{l})$, Chlorides $(43 \mathrm{mg} / \mathrm{l})$, Chromium $(0.02 \mathrm{mg} / \mathrm{l})$, Copper $(0.01 \mathrm{mg} / \mathrm{l})$, dissolved solids and total solids. The rest of the water parameters i.e. water colour (i.e. apparent colour $=36^{\circ} \mathrm{H}$; true colour $=29^{\circ} \mathrm{H}$ ), turbidity (11F.T.U.), total solids and coli form count $(1637 / 100 \mathrm{ml})$ were way above the recommended standards make the water unsuitable for human consumption. Turbidity had a positive and significant correlation ( $p<0.05$ in both cases) with Nitrates and suspended solids (Table 6). Similarly, total hardness was also positively and significantly correlated ( $p<0.05$ in all cases) with conductivity, alkalinity, Chlorides and total dissolved solids. On the other hand, total solids in the water and total coli form count were positively and significantly correlated $(p<0.05)$ to the state of the riverbank or irrigation furrows and channel width $(p<0.05)$ of riverbanks and furrows respectively. There was a weak positive regression between water turbidity and human settlements along the water systems $(\mathrm{y}=$ $0.0032 x+2.0427, R^{2}=0.008$ ) (Figure 4).

Table 5. Overall characteristics of water resources in the Kimana area

\begin{tabular}{|c|c|c|c|c|c|}
\hline & Parameter & $\begin{array}{l}\text { WHO Standards } \\
\text { (International) }\end{array}$ & $\begin{array}{l}\text { KEBS \& NEMA } \\
\text { Standards } \\
\text { (Kenya) }\end{array}$ & $\begin{array}{l}\text { Water resources } \\
\text { in Kimana area }\end{array}$ & Conclusion \\
\hline 1 & $\mathrm{pH}$ & $6.5-9.5$ & $6.5-8.5$ & 8.1 & Compliant \\
\hline 2 & Apparent Colour $\left({ }^{\circ} \mathrm{H}\right)$ & Nil & Nil & 36 & Non-compliant \\
\hline 3 & True Colour $\left({ }^{\circ} \mathrm{H}\right)$ & Nil & Nil & 29 & Non-compliant \\
\hline 4 & Conductivity $(\mu \mathrm{S} / \mathrm{cm})$ & 800 & 1000 & 284 & Compliant \\
\hline 5 & Turbidity (F.T.U.) & 5 & 5 & 11 & Non-compliant \\
\hline 6 & $\begin{array}{ll}\text { Calcium } & \text { Hardness } \\
\left(\mathrm{CaCO}_{3} \mathrm{mg} / \mathrm{l}\right) & \end{array}$ & 500 & 500 & 31 & Compliant \\
\hline 7 & $\begin{array}{l}\text { Total Hardness } \mathrm{CaCO}_{3} \\
\mathrm{mg} / \mathrm{l})\end{array}$ & 500 & 500 & 83 & Compliant \\
\hline 8 & $\begin{array}{l}\text { Total Alkalinity }\left(\mathrm{CaCO}_{3}\right. \\
\mathrm{mg} / \mathrm{l})\end{array}$ & 500 & - & 222 & Compliant \\
\hline 9 & Iron (mg/l) & 0.3 & 0.3 & 0.16 & Compliant \\
\hline 10 & Fluorides (mg/l) & 1.5 & 1.5 & 0.7 & Compliant \\
\hline 11 & Sulphates $(\mathrm{mg} / \mathrm{l})$ & 250 & 400 & 66 & Compliant \\
\hline 12 & Phosphates (mg/l) & - & - & 0.02 & Compliant \\
\hline 13 & Silica $(\mathrm{mg} / \mathrm{l})$ & - & - & 65 & Non-compliant \\
\hline 14 & Dissolved Oxygen (ppm) & - & - & 5.6 & Non-compliant \\
\hline 15 & Nitrates $(\mathrm{mg} / \mathrm{l})$ & 10 & 10 & 1.7 & Within limits \\
\hline 16 & Manganese (mg/l) & 0.1 & 0.1 & 0 & Within limits \\
\hline 17 & Chlorides (mg/l) & 250 & 250 & 43 & Within limits \\
\hline 18 & Chromium (mg/l) & 0.05 & - & 0.02 & Within limits \\
\hline 19 & Copper (mg/l) & 1 & 0.05 & 0.01 & Compliant \\
\hline 20 & Dissolved solids (mg/l) & Nil & Nil & 140 & Over the limit \\
\hline 21 & Suspended solids (mg/l) & Nil & Nil & 5.9 & Non-compliant \\
\hline 22 & Total solids (mg/l) & 1200 & 1200 & 146 & Compliant \\
\hline 23 & $\begin{array}{l}\text { Total coli form count } \\
\text { (Organisms } / 100 \mathrm{ml})\end{array}$ & Nil & 30 & 1637 & Non-compliant \\
\hline 24 & $\begin{array}{l}\text { Faecal coli form }(E . \text { coli } \\
/ 100 \mathrm{ml}))\end{array}$ & 1200 & 1200 & 16 & Compliant \\
\hline
\end{tabular}


Table 6. Correlation between water chemical and biological parameters with explanatory factors

\begin{tabular}{lllcc}
\hline & Parameter & Explanatory variables & Pearson's correlation & Significance \\
\hline 1 & Turbidity & Nitrates & 0.410 & 0.01 \\
& & Suspended solids & 0.365 & 0.01 \\
2 & \multirow{3}{*}{ Total hardness } & Conductivity & 0.876 & 0.01 \\
& & Alkalinity & 0.839 & 0.01 \\
& Chlorides & 0.807 & 0.01 \\
& TDS & 0.878 & 0.01 \\
& \multirow{3}{*}{ Total solids } & State of riverbank or irrigation furrow & 0.500 & 0.01 \\
4 & Total coli form count & Channel width of riverbanks or furrows & 0.4065 & 0.01 \\
\hline
\end{tabular}

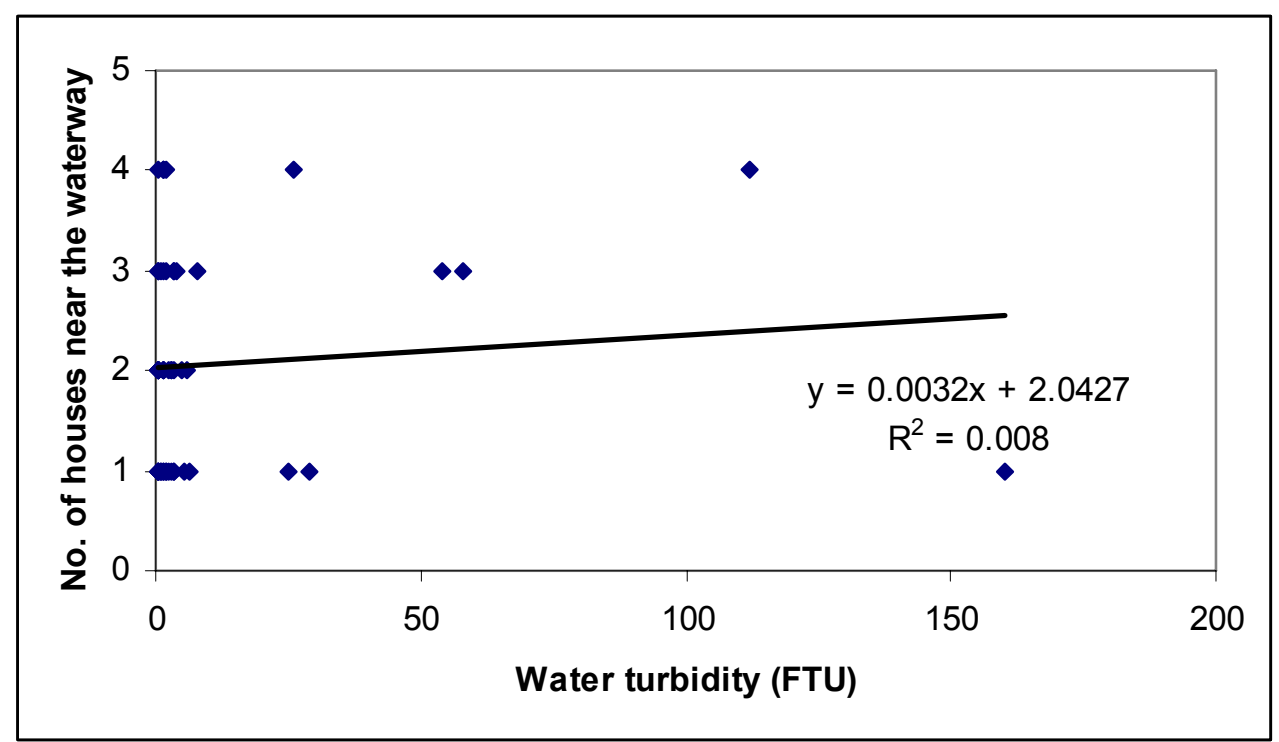

Figure 4. Simple linear regression analysis between turbidity and human settlements

The $\mathrm{pH}$ for water in the study sites and the other major rivers in the Kimana area (Kikarankot, Kimana and Isinet) ranged between 7.75 and 8.5 but it was within the set standard by WHO, KEBs and NEMA. However, at Impiron, Tikondo/Kimana and Elerai, $\mathrm{pH}$ was about 8 and above compared to that of the Kimana, Kikarankot and Isinet rivers whose $\mathrm{pH}$ was slightly more than 7 . Generally, furrows appeared to have a $\mathrm{pH}$ of 8 and above compared to rivers and springs. In terms of colour, all the water in the Kimana area was coloured and was not compliant with the set standards based on local and international criteria set for water quality and ranged between 5 and 100 (Table 5). However, water in furrows was more coloured compared to that of rivers and springs. At Impiron furrow $\mathrm{B}$ and $\mathrm{C}$ appeared to be the most coloured with true colour values of 85 and 165 respectively. In Tikondo/Kimana, water in all furrows was also coloured and had an almost equal amount of true colour ranging between 27 and 37 , while at Elerai furrow $\mathrm{C}$ and $\mathrm{A}$ had a relatively higher water colour in relation to the other furrows.

All the steams and springs in the Kimana area had coloured water but water in Kikarankot river was the most coloured with a true colour value of 100 compared to Kimana and Isinet rivers whose true colour values were equal at 5. The amount of Fluorine, Iron and level of water alkalinity was slightly below the WHO, KEBs and NEMA standards. However, the amounts of suspended solids in all the water sources were above the set standards by WHO but below those of KEBs and NEMA. Generally, water in furrows seemed to have more suspended solids than rivers and springs but Kikarankot river appeared to have more solids than other rivers and springs that are found in the Kimana area. Coli forms were found in most of the water sources and were therefore above the set international and Kenyan standards. Total coli forms were relatively high in most of the water but they appeared to be generally higher in furrow waters than in springs and streams (Table 5). Overall, water from furrows and 
springs at Tikondo/Kimana and Elerai had more total coli forms than Impiron. Kimana, Kikarankot and Isinet rivers had very high levels of Total coli forms (Kikarankot $=1120$ organisms $/ 100 \mathrm{ml}$, Kimana $=860$ organisms $/ 100 \mathrm{ml}$ and Isinet $=1170$ organisms $/ 100 \mathrm{ml}$ ) and only Kikarankot river had faecal coli form (Escherichia coli).

\subsection{Assessment on the Environmental Status Around Water Sampling Points}

Four vegetation cover types and three dominant woody vegetation cover classes were observed across the three study sites. The percentage cover of trees and grasses was $48 \%, 45 \%$ and $69 \%$ at Impirioni, Tikondo and Elerai respectively. Percentage cover of areas with trees and bare ground ranged between $23 \%$ and $27 \%$ with Impironi having about $26 \%$ of this cover type while at Tikondo and Elerai was $27 \%$ and $23 \%$ respectively. In all the three sites, cultivated river/spring banks covered by different types of crops were observed and covered about $26 \%$ of the areas at Impironi, $18 \%$ at Tikondo and $8 \%$ at Elerai (Table 7). Overall, the percentage of vegetation cover types were not dependent on the study sites $\left(\chi^{2}=6.069, \mathrm{df}=6, \mathrm{p}=0.415\right)$. Three classes of dominant woody vegetation types were observed along the water sampling sites in the study sites and these were dependent on site $\left(\chi^{2}=21.77\right.$, $\mathrm{df}=4, \mathrm{p}<0.001)$.

Table 7. The physical environment around water sources (water and furrows) in Kimana area

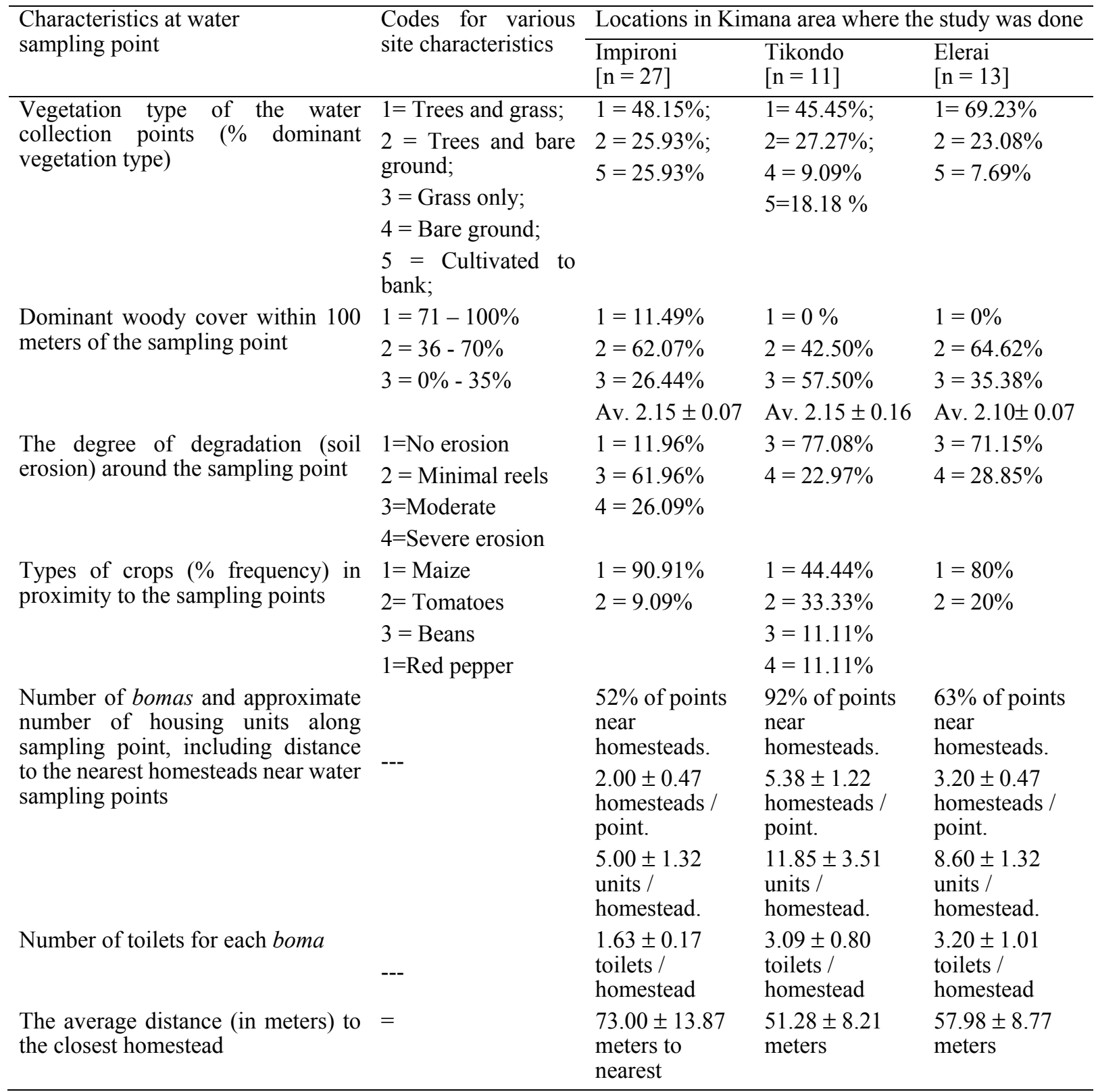


Incidences of soil erosion were observed along most water systems in the study sites but the level of erosion was not dependent on the site $\left(\chi^{2}=2.872, \mathrm{df}=4, \mathrm{p}=0.580\right)$. All the sites were moderately eroded and incidences of severe erosion were relatively low (Table 7). At Impironi, about $62 \%$ of the water sampling was moderately eroded with $26 \%$ of them being severely eroded. Similar trends were observed at the other sites with $77 \%$ and $23 \%$ of the water sampling areas at Tikindo having moderate and severe erosion. In Elerai, about $29 \%$ of the water sampling areas had severe erosion compared to $71 \%$ with moderate erosion.. Four crop types were found close to the water sampling areas across the sites but maize and tomatoes were the most common (Table 7). In Impironi and Elerai, maize was found close to $91 \%$ and $80 \%$ of the water sources respectively, and in about $44 \%$ of the areas at Tikondo. However, the occurrence of crops grown close to water sources was dependent on the site $\left(\chi^{2}=13.497, \mathrm{df}=6\right.$, $\mathrm{p}=0.036$ ) with tomatoes being grown in all the three sites while pepper and beans were grown at Tikondo.

Human structures mainly toilets, homesteads and schools were found along the water sources and in close proximate to the water sampling sites (Table 7). Homesteads were recorded in $92 \%, 63 \%$ and $52 \%$ of the water sampling sites at Tikondo, Elerai and Impironi respectively. On average, the number of homesteads close to water sources varied between 2 and 5 and was significantly different among the sites $(F=3.53 ; d f=2,29 ; p=0.043)$ and was higher at Tikondo. In Tikondo, the average number of house units was higher followed by Elerai and lastly Impironi. However, there was no significant difference in the average number of house units per homestead across the study sites $(\mathrm{F}=1.65, \mathrm{df}=2,29, \mathrm{p}=0.210)$. Although toilets were recorded in homesteads water sources, a majority of them lacked these facilities. The average number of toilets at Tikondo was highest followed by Elerai and lastly Impironi. The number of toilets per homestead did not vary significantly across the study sites $(\mathrm{F}=0.988$; $\mathrm{df}=2,26 ; \mathrm{p}=0.386$ ). Through the study sites, homesteads were found close to water sources with the average distance ranging from $57 \mathrm{~m}$ to $73 \mathrm{~m}$ (Table 7 ) but it did not differ significantly among the sites $(\mathrm{F}=1.053, \mathrm{df}=2,27$, $\mathrm{P}=0.363$ ).

\section{Discussion}

There was a general agreement among the local community that water quantity in the Kimana area has been declining over time. The measurements taken by WRMA also back this sentiment but; the cause of decline is not attributed to the discharge rate but over-abstraction along the waterways. Thus, causes for the decline are mainly anthropogenic, although natural causes such as localized climatic changes were also thought to be responsible. Therefore, it is the human causes that need urgent redress. The consequences of such decline in water quantity have been low productivity (crop and livestock), prevalence of waterborne diseases, local water conflicts and reduced quality of life. Further, the over-abstraction in Kimana, most of which is illegal, has led to the surface water resources being in a highly threatened state. The Kimana river system is dying and so is the Kimana wetland which has been rapidly encroached by the opening up of new farms and an intensified use of water in the old farm (Okello \& Kioko, 2011). The water sources discharging into the wetland have been abstracted to the extent that that there is only minimal environmental flow into the wetland except for Kimana River.

In order to arrest and where possible reverse this trend, the way forward is to secure water sources, diversify water sources (other than springs and rivers) such as boreholes, harvested rain water from house roofs, collecting flood water during the rainy season and storing it in earth dams, conserving local catchment areas through rehabilitation of riverine habitats, and swamps. Further, general environmental conservation such as control of soil erosion and the reduction/reversal of degradation by maintaining healthy vegetation cover through the control of charcoal burning and reduction of overgrazing may improve water discharge.

There is also a need to adhere to existing environmental policies and laws. As it is, there is violation of various sectoral laws (water, agriculture and environmental) which should otherwise be adhered to during water harvesting and use. For example, the Kalesirua canal which gets its water from Isinet River, abstracts more water from the source $\left(0.090 \mathrm{~m}^{3} / \mathrm{s}\right)$ than what is left in River $\left(0.074 \mathrm{~m}^{3} / \mathrm{s}\right)$. Ensuring that agriculture and human settlements are kept away from water sources will help secure such sources and keep them healthy and maintain natural flow over time. There is also need for the governments to consider provisioning water from the Noolturesh pipeline to people and livestock so as to ensure they have easy access to sufficient and clean throughout the year.

Crop rotation is an important aspect of good crop husbandry because it rejuvenates the soil, as well as giving an opportunity for land to maximize production from crops of different water and nutrient demands. With maize, beans, tomatoes, onions and French beans being the most commonly grown crops in the region, it is possible to attain a good combination because beans and French beans are nitrogen fixing plants which enrich the soil and hence when rotated with cereals like maize increase productivity. However, this is not the case, and most farmers prefer to grow crops with good income, but some of them like onions and tomatoes are high water demand crops which in terms of limited water quantity are the ones that are most likely to fail in instances of water shortage. In 
this regard, we recommend that crops that use less water (especially indigenous varieties) be explored and introduced into the area by the relevant actors to boost not only production but also to act as a hedge against droughts due to their hardiness.

There were several crop failures reported due to three main reasons: reduced water quantity, wildlife damages and poor weather. This is a significant finding because it points to what will eventually limit agriculture expansion in the Kimana area specifically and other arid regions of the country in general. Lack of water and wildlife damage are the most common problems besetting farmers and are also most likely to get out of hand, hence leading to high economic loss of revenue. With malfunctioning electric fences and high costs of agriculture inputs in Kenya, these two aspects are likely to constraint further agricultural expansion in all areas of Kimana. Additionally, lack of irrigable land is another factor that will is also likely to exacerbate the decline in agriculture expansion in the area. These three factors may be contributing to what is already apparent in the area in terms of farmers not expanding the acreage under agriculture. There could also be other reasons such as increased number of farms and farmers interested in cultivation as it's relatively a more lucrative land use than either pastoralism or wildlife.

Depressed agricultural production due to a reduction in water quantity, bad weather, increased wildlife damages and diminished irrigable land as a result of an increased human population will reduce agricultural productivity in the area. This has two impacts: firstly, for commercial horticultural production that has been the main source of revenue in the area, reduced productivity will reduce job opportunities not only for farmers but all other businesses related to agriculture such as transportation, suppliers and vendors of agriculture inputs. Secondly, it will reduce the amount of food planted for subsistence use leading to a reduction in household food security. The area is already a main recipient of foreign food aid, and so such reduced food security will exacerbate impoverishment of the local community which may be manifested as malnutrition, especially in children and disadvantaged in society.

On the issue of conflict with wildlife, there is need to allow more water to flow downstream to avoid attracting wildlife into people's farms as they seek for water. On the other hand, due to the collapse of the EU funded fences, because of lack of ownership, maintenance and provision of spare parts and funds for maintenance, the Kenya Wildlife Services problem animal control will have to be more vigilant to reduce such costs. We recommend that opportunities to rehabilitate the fence be explored as a way of reducing wildlife - induced crop damages and contain the persistent human - wildlife conflicts in the area.

Due to low-end irrigation technology used by farmers in Kimana, mostly basin and furrow irrigation systems, there is rapid salinization of the soil's upper layers as well as a massive loss of water to the lower levels from high level of evapo-transpiration and percolation respectively. To control this, it is important to explore the possibility of introducing irrigation systems that use water efficiently such as drip irrigation or porous clay pot method which allow gradual release of water into the soil thus limiting loss from percolation of excess water. The other way is to ensure that little water sips through the soil by ensuring that as many irrigation canals as possible are cemented. This will increase the flow rate of water to farms and hence reduce underground loss, and also address the amount of water available to each farmer.

As it regards to water quality, most of the parameters analyzed and found to be within the KEBS / WHO / Nema acceptable levels were mainly chemical parameters. However, it should be noted that they were on the rise and increasing and therefore require monitoring. Most of these parameters may take long to reach unacceptable levels that would cause healthy concerns in the community, but they seem to be increasing as they arise mainly from agro -chemical sources, and degradation of the environment.

The findings of this study indicated the rivers in the study area were suffering more from a decline in physical quality rather than decline in chemical quality. However, the most serious problem in most of the rivers is a poor state in biological quality due to the presence in water of high levels of faecal coli forms most likely due to poor sanitation. Therefore, the water quality in most water sources in Kimana Area was found to be unsuitable for domestic utilization. This is of great concern since the biological aspects of water is the one which is associated most closely with a community's health and wellbeing. It is therefore important for all stakeholders to realize that all water sources in Kimana area are unsuitable for human consumption.

There are several strategies that can be used to mitigate this situation. First and foremost, it means most contamination is from human waste as a result of improper disposal and management therefore ending up in water sources. This also means that there are very few people that use toilets for waste disposal or generally do not use the toilets at all (but relief themselves in bushes). It also means that even where there are toilets, they may be shallow or located closer to water and during the wet season floods, they overflow and leak into water systems. To eliminate this outcome, every member of the community needs to use toilet facilities that are properly dug to an appropriate depth and located further away from water sources and systems. Further, each homestead must be 
encouraged to have a toilet facility. This can be done through awareness and enforcement by public health officers, and it is already taking root in the neighboring Mbirikani Group Ranch through the intervention of local community Clinic. Another alternative is for the government to provide safe drinking water. This is only possible if the clean water from Kilimanjaro (Noolturesh water System) that has been piped from the area to Kitengela can be diverted to supply homesteads and market centers along the pipeline. Such an action will provide sealed-in water that is not exposed and vulnerable to contamination from human waste and other pollutant sources. On the other hand it will be prudent to encourage the community to treat water used for drinking through the use of cheap and locally available chemical treatment or simply by boiling.

It was noted from the laboratory tests that all water sources in the area were unsafe for drinking in its untreated form. This is an important revelation, first because everyone in the area needs to be warned of the dangers to their health for drinking any untreated water from any source in the area. But secondly, it means that water sources need enhanced protection and security from all forms of pollution and contamination. There is need to criminalize every form of deliberate (and even unintended) water pollution or discharge of water contaminants that would compromise the water quality and endanger public health in the area. Therefore fencing water catchment areas and all springs / rivers from which comes drinking water needs to be done urgently. A few NGO's have attempted this in the past with moderate success and have already done some work, although this is no longer ongoing. In such cases, the previous initiatives have collapsed and fences around water sources removed. Currently, there a few initiatives towards this end such as the Noomayianat Community Development Organization / AWF, and Noomayianat Community Development Organization / The School for Field Studies through CEF / CTDF Funded Kimana Water Conservation Project who are involved in rehabilitation, securing and fencing of water sources.

Laboratory results also showed that water quality was reduced by presence of total coli form . This type of contamination normally arises from a high presence of animal faecal material in the water. This is especially high for furrow systems compared to springs and rivers. It is also most prevalent in areas which water frequently from furrow systems (such as Tikondo / Kimana and Elerai, which had relatively high total coli forms than in Impiron). It therefore means that most water sources are contaminated by both human and animal (mostly livestock) waste who water in same sources and systems human drinking water is obtained from. It is common for livestock to defecate and urinate in water when they drink, and so this contamination becomes enhanced when there are large herds of livestock visiting water sources, and on a daily basis, and especially if they also graze in the same area especially during the dry season. To eliminate this contamination, it will be critical for different watering points established for livestock and domestic drinking use. Further, it is also advised that people should avoid drawing water for drinking, cooking and general domestic use from furrow systems. Also based on the finding that feacal coli forms (Escherichia coli) were also detected in Kikarankot river (but absent in other river systems in the area) it is recommended that hotels and lodges in the area be monitored to ensure that they are not discharging effluents into river systems.

Another serious water quality issue is the amount of suspended solids and general high water turbidity in the area. Most of the rivers had high turbidity and low water transparency making the water quality unsuitable for human consumption. The furrows seem to be more affected by suspended solids and high turbidity compared to springs and rivers. The causes for this are high levels of degradation arising from plant cover reduction and over exploitation of plant resources in the area. Most of river systems have trees and shrubs cleared for agriculture or for charcoal burning. When the trees and shrubs are present, the ground is till bare due to overgrazing which is most intensive in the dry season. This exposes the soil to different agents of soil erosion, with most soils being deposited in water systems, hence increasing suspended solids and increasing turbidity and overall water quality for human use. If such water is used without treatment, this might be a key cause of gastroenteritis and abdominal diseases in the area. Efforts must therefore be made to improve the quality of water in all water systems, as well as a more general proactive approach to environmental conservation which depends on a healthy vegetation cover.

\section{Conclusion}

This study has shown that both water quantity and quality in Kimana area is declining. Many stakeholders, community members, key opinion leaders, medical practitioners, government officials and group ranch officials and local administrators all consistently gave the same observation. This was corroborated by field observations, examination of medical records on waterborne disease prevalence, and laboratory tests on water quality. The main causes for the perceived water quantity decline were increase in human population, increase in irrigated agriculture, and weather changes. The main causes for the decline in water quality levels were water pollution from domestic and livestock waste, contamination from agro - chemicals, increased suspended water solids and particulate matter that led to reduced water turbidity, lack of designated watering place for humans and livestock, poor sanitation, 
illegal washing of vehicles, humans and cloths in drinking water sources and increased human encroachment through settlements closer to water sources.

Further there is a general lack of enforcement of existing water policy, laws and guidelines by relevant government ministries and environmental agencies to the extent that water management is non - existent and there are no proper local institutions that manage water use, conservation and access in the area. Many people extract was as they see fit in terms of quantities, divert entire rivers into their agricultural fields, draw any quantity of water by any means without proper permits, regard to other users especially downstream, in total disregard of existing guidelines nor minding the accompanying consequences. The past initiatives in the area have mostly been the NGO's and mostly focused on irrigated canal cementing. However, recent initiatives have been well planned by also NGO's by involving the local community in all stages of project implementation and focus not only on cementing irrigation canals, but also securing water sources, conserving water systems and creating awareness (both environmental and conservation ) associated with water resources. There has also been conflicting policies and framework (Agricultural Act and Water Act), thus creating more confusion in water management and use initiatives in the area. Further, it is not clear which ministry is responsible for what aspect of water conservation and management among the ministry of environment, Ministry of Water and Irrigation, Ministry of Agriculture, the various statutory water bodies (WRMA, WRUAs etc.) and the group ranch management structure.

The consequences of a decline in water quantity and quality have been increased prevalence of waterborne diseases in the area. These include dysentery, amoebiosis and typhoid which are most noticeable in the dry season when water resources diminish and people are compelled to use whatever water they can find. This especially so due a general believe by the local community that water from its sources is still safe in its untreated form. This has led to little effort in treating water (by boiling or chemical treatment) and hence this could explain the prevalence of these diseases. With generally low levels of education and awareness, and knowledge in hygiene and how such diseases spread, prevalence is always high, and local community spend time and money in treatment both in local and public health centers in the area. Further, the issue of water quality has been degenerated further due to a lack of general lack of proper stewardship of the environment in the area as a result of communal ownership of resources or just luck of education and awareness. This compromised stewardship has led to increased degradation of water resources and the environment in general. The depletion of plant cover and overgrazing around water sources and systems, has led to high levels of suspended solids and particulate matter in water.

Reduction of water quantity has also led to local conflicts in the area. Even though most members of the community do not think that these conflicts are serious, they are increasing and gradually moving from mere verbal exchanges to fatal conflicts in the near future. Such conflicts show competition for water resources by different users, and point to a future of serious conflict if management and resolution of such conflicts is not done by experienced and trained people, and effective resolution done to the satisfaction of all parties involved in the conflicts. It is recommended that these issues be dealt with urgently to avoid further crisis in the water situation in the Kimana Area.

\section{Acknowledgements}

This study could not have been undertaken successfully without the support and input of different persons. In particular, we would like to thank the entire Project Implementation Committee (PIC) for the Kimana Water Conservation Project for giving The School for Field Studies (SFS)-Centre for Wildlife Management Studies (CWMS) an opportunity to undertake this study. We sincerely appreciate and acknowledge the local community members who participated, key informants; local guides who collected the data, health practitioners who provided data on water borne diseases, and all the political and administration leaders who made this work possible.

\section{References}

Campbell, D. J,. Gichohi, H., Mwangi, M., \& Chege, L. (2000). Land use conflict in Kajiado District, Kenya. Land Use Policy, 17, 337-348. http://dx.doi.org/10.1016/S0264-8377(00)00038-7

Campbell, D. J., Lusch, D. P., Smucker, T., \& Wangui, E. E. (2003). Root causes of land use change in the Loitokitok area Kajiado Districvt, Kenya. Land Use Change Impacts and Dynamics (LUCID) Working Paper Number 19. International Livestock Research Institute, Nairobi, Kenya.

Galaty, J. (1992). The land is ours: social and economic factors in the privatization, sub-division and sale of Maasai ranches. Nomadic peoples, 30, 26-40.

Githaiga, J. M., Reid, R., Muchiru, A. N., \& van Dijk, S. (2003). Survey of water quality changes with land use type in the Loitokitok Area, Kajiado District, Kenya. Land Use Change Impacts and Dynamics (LUCID) Working Paper Number 35. International Livestock Research Institute, Nairobi, Kenya. 
Government of Kenya (GoK). (2005). Ministry of Water and Irrigation. Hand Book on Water Sector Reforms.

Government of Kenya (GoK). (2007). Ministry of Water and Irrigation. National Policy and Irrigation and Drainage Development.

Hardin, G. (1968). The tragedy of the commons. Science, 162,1243-1248. http://dx.doi.org/10.1126/science.162. 3859.1243

Katampoi, K., Genga, G., Mawngi, M., Kipkan, J., Seith, J, Van Klinken, M. K., \& Mwangi, M. S. (1990). Kajiado District Atlas. ASAL Programme, Kajiado Kenya.

Kimani, K., \& Pickard, J. (1998). Recent trends and implications of group ranch subdivision and fragmentation in Kajiado District, Kenya. The Geographical Journal, 164, 202-218. http://dx.doi.org/10.2307/3060370

Kioko, J., Kiringe, J. W., \& Seno, S. (2012). Impacts of livestock grazing on a savanna grassland in Kenya. Journal of Arid Land, 4(1), 29-35. http://dx.doi.org/10.3724/SP.J.1227.2012.00029

Kiringe, J. W., \& Okello, M. M. (2005). Use and availability of tree and shrub resources on Maasai rangelands near Amboseli, Kenya. African Journal of Range and Forage Science, 22(1), 37-45. http://dx.doi.org/10. 2989/10220110509485860

Mackereth, F. J., Heron, J., \& Talling, J. F. (1989). Water Analysis: Some Revised Methods for Limnologists. Freshwater Biological Association. Scientific Publication No. 36, Cumbria

Mogaka, H., Gichere, S., Davis, R., \& Hirji, R. (2006). Climate variability and water resources degradation in Kenya: improving water resources and development and management. World Bank working paper No. 69.

Mueller-dombois, D., \& Ellenberg, H. (1974). Aims and methods of vegetation ecology. New York: John Wiley and Sons Inc.

Ntiati, P. (2002). Group ranches subdivision study in Loitokitok Division of Kajiado District, Kenya. The Land Use Changes, Impacts and Dynamics (LUCID) Project Working Paper Number 7. International Livestock Research Institute, Nairobi, Kenya.

Okello, M. M. (2005). Land use changes and human-wildlife conflicts in the Amboseli area, Kenya. Human Dimensions of Wildlife, 10(1),19 -28. http://dx.doi.org/10.1080/10871200590904851

Okello, M. M., \& D'Amour, D. (2008). Agricultural expansion within Kimana electric fences and implications for natural resource conservation around Amboseli National Park, Kenya. Journal of Arid environments, 72, 2179-2192. http://dx.doi.org/10.1016/j.jaridenv.2008.07.008

Okello, M. M., \& Kioko, J. M. (2011). A field study in the status and threats of cultivation in Kimana and IIchalai swamps in Amboseli dispersal area, Kenya. Natural Resources, 2, 197-211. http://dx.doi.org/10.4236/nr. 2011.24026

Pratt, D. J., \& Gwynne, M. D. (Eds.) (1977). Rangeland management and ecology in East Africa. Hodder and Stoughton, London England.

Reid, R. S., Gachimbi, L. N., Worden, J., Wangui, E. E., Mathai, S., Mugatha, S. M., ... Ogol, E. (2004). Linkages between changes in land use, biodiversity and land degradation in the Loitokitok Area of Kenya. Land Use Changes, Impacts and Dynamics (LUCID) Project Working Paper Working Paper No. 9. International Livestock Research Institute, Nairobi, Kenya

Western, D., \& Lindsay, W. K. (1984). Seasonal dynamics of a savanna elephant population. African Journal of Ecology, 22, 229-244. http://dx.doi.org/10.1111/j.1365-2028.1984.tb00699.x

Wild Wildlife Fund for Nature. (WWF). (ND). Water shorage. Retrieved from www.wetland.azgro.nl \& www.panda.org/livingwaters.

Zar, J. (1999). Biostatistical Analysis (4th ed.). Englewood Cliffs, New Jersey: Prentice-Hall, Inc.

\section{Copyrights}

Copyright for this article is retained by the author(s), with first publication rights granted to the journal.

This is an open-access article distributed under the terms and conditions of the Creative Commons Attribution license (http://creativecommons.org/licenses/by/3.0/). 